\title{
Огляд 15-го Міжнародного конгресу, присвяченого діагностиці та лікуванню лімфом (ICML), Лугано, Швейцарія, 18-22 червня 2019 р.
}

\author{
Національний інститут раку, Київ \\ Одержано 19.08.2019 \\ Підиисано до друку 19.09.2019 \\ DOI: 10.32471/clinicaloncology.2663-466X.40.22889
}

\begin{abstract}
У цій оглядовій статті наведено найважливіші нові досягнення, що були представлені у м. Лугано, Швейцарія, в рамках 15-го Міжнародного конгресу, присвяченого діагностиці та лікуванню лімфом (ICML). Висвітлено ключові рекомендації Міжнародної онкологічної групи з питань променевої терапії при лімфомах та наведено посилання на рекомендації цієї групи щодо променевої терапії при дифузних В-великоклітинних лімфомах та множинній мієломі/плазмоцитомі. Надано остаточні та проміжні результати останніх досліджень при таких нозологіях, як хронічний лімфолейкоз, індолентні лімфоми, великоклітинні лімфоми високого ризику, лімфоми із клітин мантійної зони, лімфома Ходжкіна, наведено оцінку ефективності новітніх моноклональних антитіл та інших новостворених досліджуваних препаратів, а також можливості лікування лімфом без хіміотерапії.
\end{abstract}

Ключові слова: лімфома, лімфома Ходжкіна, неходжкінська лімфома, множинна мієлома, ICML, 15-й Міжнародний конгрес, присвячений діагностиці та лікуванню лімфом.

\section{вступ}

18-22 червня 2019 р. у м. Лугано, Швейцарія, відбувся 15-й Міжнародний конгрес, присвячений діагностиці та лікуванню лімфом (ICML), який відвідали 3800 учасників з більш ніж 90 країн світу. У рамках конгресу було вручено дві нагороди (Gianna Bonadonna та Henry Kaplan Memorial) за видатні досягнення в галузі дослідження патології лімфом. Цього року призерами стали А.M. Melnick (США) та С.Н. June (США) за досягнення в галузі епігенетичної терапії лімфом та розробку наступного покоління CAR-T-клітинної терапії відповідно. Ключовими темами для обговорення в ході даного конгресу були новітні препарати та їх комбінації, нові конструкції для CAR-T-клітинної терапії, великі масиви даних у біології, персоналізований підхід у терапії, дослідження, що можуть змінити клінічну практику. Важливою частиною заходу стала закрита робоча нарада з питань впровадження «рідкої біопсії» у лікування пацієнтів з лімфомою. Визнана складність даної методики та іiі значення при діагностиці, на різних етапах лікування та після завершення терапії лімфом. Основним висновком засідання було рішення щодо необхідності стандартизації даного методу з метою використання його для оцінки мінімальної залишкової хвороби. Окрема секція у форматі дебатів та лекція відомого вченого із США V. Rajkumar були присвячені високій вартості нових препаратів для терапії лімфом та множинної мієломи і пошукам шляхів вирішення цієї проблеми на рівні держави, фармацевтичних компаній, професійних та пацієнтських організацій і лікарів.

\section{ПРОМЕНЕВА ТЕРАПІЯ}

У рамках конгресу відбулося засідання Міжнародної онкологічної групи з питань променевої терапії при лімфомах.

Зокрема, обговорено нові стандарти променевої терапії (ПТ) для солітарної плазмоцитоми та множинної мієломи [1] від Міжнародної онкологічної групи з питань променевої терапії при лімфомах. Згідно із цими рекомендаціями для забезпечення знеболювального ефекту при лімфопроліферативних захворюваннях достатньо сумарної дози 8 Грей $(Г р)$ за один сеанс ПТ. Для зняття компресії спинного мозку при множинній мієломі однаково ефективним є короткий курс ПТ (8 Гр одноразово або 5 сеансів по 4 Гр) та більш тривалий курс ПТ (10 сеансів по 3 Гр). Також експерти даної групи підкреслювали відсутність кореляції дози при солітарній плазмоцитомі та частоти локаль- них рецидивів і наголошували, що 35-40 Гр є достатньою дозою для невеликих пухлин, тоді як 40-50 Гр слід застосовувати для пухлин більше 5 см. При плануванні ПТ з паліативною метою оптимальною дозою $є 10$ Гр.

Під час доповіді про ПТ при рецидивних/рефрактерних формах дифузних В-великоклітинних лімфом (ДВКЛ) [2] було вказано, що для пацієнтів, які не є кандидатами на трансплантацію, з хорошим загальним станом рекомендовано проводити опромінення в дозі 45-55 Гр (з метою виліковування), фракціями по 1,8-2 Гр та 8-30 Гр для пацієнтів з паліативною метою. У той час як для пацієнтів, що $є$ кандидатами на трансплантацію, ПТ може бути проведена як до, так і після високодозової терапії. За умови швидко прогресуючого захворювання доза може бути підвищена до 40-50 Гр, або до 35-40 Гр фракціями по 1,3-1,5 Гр 2 рази на добу у поєднанні з цисплатинвмісними режимами.

Експертами даної групи проводилося обговорення широкого розповсюдження даних рекомендацій та впровадження їх у клінічну практику.

\section{ДИФУЗНІ В-ВЕЛИКОКЛІТИННІ ЛІМФОМИ}

Згідно з результатами останніх досліджень отримано суперечливі висновки щодо терапії пацієнтів з ДВКЛ з включенням леналідоміду до стандартної схеми R-CHOP: 2 дослідження, 2 дизайни, 2 різних результати. У доповіді U. Vitolo були представлені результатів дослідження ROBUST «Перші результати III фази рандомізованого дослідження леналідомід/R-CHOP (R2-CHOP) та плацебо/R-CHOP у пацієнтів з АВС-підтипом ДВКЛ» та в доповіді G. Nowakowski результати дослідження II фази ECOG-ACRIN1412 «Додавання леналідоміду до R-CHOP (R2-CHOP) для покращення результатів лікування ДВКЛ»: не виявлено жодної різниці у виживаності, за даними італійської групи дослідників (1-річна безрецидивна виживаність (БРВ) 67 та 64\%), та відзначено зниження ризику прогресії чи смерті на $34 \%$ при додаванні леналідоміду згідно з даними групи ACRIN-ECOG. Відмінність у результатах досліджень можна пояснити різними групами пацієнтів (АВС проти всіх ДВКЛ), різними дозами та схемами призначення леналідоміду, різними фазами досліджень (II та III) і їх дизайном. Отже, на даний момент стандартом терапії при ДВКЛ залишається режим R-CHOP. Численні дослідження спрямовані на пошук нових підходів до покра- 
щення режимів терапії хворих на ДВКЛ, зокрема «double/triple hit» - групи пацієнтів за найбільш несприятливим прогнозом.

У секції «Фокусуємося на...» представлено результати, які свідчать, що високодозова хіміотерапія (ВДХТ) з аутологічною трансплантацією стовбурових клітин (АТСК) у першій ремісії при лімфомі із клітин мантійної зони (МКЛ), за даними A. Zoellner, суттєво подовжує БРВ та загальну виживаність (3В). Вчені доповіли про результати 14-річного рандомізованого дослідження MCL-1, у ході якого порівнювали консолідацію з мієлоаблятивною ПТ після 4-6 курсів СНОР-подібної індукційної терапії з наступною АТСК та підтримувальною терапією інтерферонами у пацієнтів з МКЛ у період першої ремісії. У пацієнтів групи, що отримувала АТСК, БРВ становила 3,3 року у порівнянні з 1,5 року у пацієнтів, що отримували підтримувальну терапію інтерферонами ( $<00,0001)$. Окрім того, медіана 3В у пацієнтів після АТСК становила 7,5 року у порівнянні з 4,8 року в групі пацієнтів, що отримували інтерферони $(\mathrm{p}=0,019)$. Представлено дані про новий препарат занабрутиніб, що належить до селективних інгібіторів тирозинкінази Брутона. За результатами мультицентрового дослідження II фази досліджуваний препарат призначали у дозі 160 мг 2 рази на добу пацієнтам з рефрактерною/рецидивною формою МКЛ до прогресування або вираженої токсичності. Показник загальної відповіді становив 84,7\%, і 65 пацієнтів (76,5\%) досягли повних відповідей. Медіана БРВ становила 16,7 міс. Результати цього дослідження свідчать про високий рівень тривалих відповідей на терапію занабрутинібом з прийнятним профілем токсичності.

\section{ПОЗИТРОННО-ЕМІСІЙНА ТОМОГРАФІЯ}

У секції, присвяченій позитронно-емісійній томографiï (ПЕТ), M. Novo (США) були представлені цікаві результати досвіду одного центру щодо залишкового накопичення фтордезоксиглюкози в середостінні після терапії першої лінії хворих 3 класичною лімфомою Ходжкіна (ЛХ). Часто у цих випадках важко відрізнити залишкову хворобу і запальні зміни після лікування. Серед 1060 пацієнтів з ЛХ 37 були включені у дослідження. Біопсія середостіння була проведена в 19 з 37 випадків (група 1). У 9 з 19 (47\%) у гістологічному матеріалі верифіковано наявність ЛХ, і пацієнти отримали терапію другої лінії з подальшою АТСК (група 1a). Серед негативних випадків (група 1b) 4 пацієнти залишилися під спостереженням, а 6 iз 10 було проведено консолідацію ПТ. Серед пацієнтів, котрим не проводилася біопсія (група 2), під спостереженням залишилися 10 iз 18 (група 2a), 7 із 18 отримували ПТ (група 2b), а один із 18 отримав терапію з подальшою АТСК (група 2c). Після завершення запланованого лікування проведено повторну ПЕТ/комп'ютерну томографію (KT) у 34 із 37 пацієнтів. За шкалою Deauville (DS) результати були наступними: 3 випадки DS2, 4 - DS3, 12 - DS4, 12 - DS5, замішення тимусу у 3 пацієнтів (DSX). Частота рецидивів становила $1 / 3(33 \%)$ для DS2, $1 / 4$ (25\%) для DS3, 4/12 (33\%) для DS4, 10/12 (83\%) для DS5 і 1/3 (33\%) для DSX. У межах цієї невеликої ретроспективної когорти біопсія персистуючого залишкового ПЕТ-позитивного вогнища у середостінні після лікування була позитивною у менше ніж 50\% пацієнтів, i DS не відігравав ролі у відборі пацієнтів з потенційно рефрактерним захворюванням. Автори дійшли висновку, що тактика «очікуй і спостерігай» з повторною ПЕТ/КТ через 8-12 тиж та проведенням біопсії за необхідності тільки після повторних позитивних ПЕТ/КТ може бути оптимальною опцією.

За даними A. Cottereau та співавторів, великий загальний метаболічний об'єм пухлини (TMTV) за даними ПЕТ/КТ перед початком терапії за схемою R-CHOP асоціюється з гіршою БРВ та ЗВ у пацієнтів з ДВКЛ. Результати клінічного дослідження REMARC (NCT01122472) продемонстрували кращу БРВ у пацієнтів, що отримували підтримувальну терапію леналідомідом у порівнянні з групою, що приймала плацебо. Однак відмінностей у ЗВ хворих у різних досліджуваних групах виявлено не було. На основі даних дослідження було проаналізовано прогностичний вплив TMTV до початку лікування.
Оптимальним пороговим значенням TMTV був об'єм пухлини $220 \mathrm{~cm}^{3}$. У пацієнтів з TMTV $>220 \mathrm{~cm}^{3}$ та TMTV $\leqslant 220 \mathrm{~cm}^{3} 4$-річна БРВ становила 56 проти $82 \%$ і 3В - 74 проти 92\% відповідно $(\mathrm{p}<0,05)$. Така різниця у виживаності зберігалася і при аналізі за підгрупами (леналідомід проти плацебо) та при розподілі за клітинним походженням ДВКЛ (GCB/non-GCB).

У цій секції також були представлені дані P. Strati щодо прогностичного значення ПЕТ/КТ до початку лікування при фолікулярній лімфомі (ФЛ). Так, автори проаналізували прогностичний вплив SUVmax у 346 пацієнтів з ФЛ, що отримали лікування в MD Anderson Cancer Center з 08.2001 до 04.2014 p. За результатами цього аналізу було показано, що високе значення SUVmax є несприятливим прогностичним фактором у пацієнтів з розповсюдженими стадіями ФЛ, що отримували ритуксимабвмісну терапію, оскільки може свідчити про недіагностовану трансформацію ФЛ у ДВКЛ чи більш агресивну за своєю біологією пухлину.

У секції, присвяченій клінічним даним з вивчення ДВКЛ, J.R. Westin презентував результати терапії ритуксимабом, леналідомідом та ібрутинібом перед стандартною хіміотерапією першої лінії у пацієнтів з ДВКЛ (дослідження Smart Start). У дослідження було включено 60 пацієнтів 3 non-GCBпідтипом ДВКЛ, визначених за алгоритмом Нans із задовільним загальним станом та функцією органів. Первинною метою дослідження було визначення загальної відповіді на лікування після 2 курсів терапії із застосуванням ритуксимабу, леналідоміду та ібрутинібу та частоту повних відповідей після 6 додаткових курсів хіміотерапії та даної комбінації. Показник загальної відповіді після 2 курсів становив 84,6\% (n=44), частота повних відповідей $-38,5 \%(n=20)$. Один пацієнт відмовився від подальшої запланованої хіміотерапії після зареєстрованої відповіді в результаті 2 курсів та залишається в ремісії протягом 18 міс спостереження. Після завершення повного обсягу терапії частота повних відповідей становить 100\%. Автори підсумовують, що попередні результати дослідження Smart Start свідчать, що комбінація препаратів без хіміотерапії (ритуксимаб 375 мг/м², ібрутиніб 560 мг і леналідомід 25 мг є високоефективною у пацієнтів 3 non-GCВ підтипом ДВКЛ. Планується проведення подальших досліджень для оцінки ефективності нових препаратів з меншою кількістю консолідаційних курсів хіміотерапії для пацієнтів, що досягли повної ремісії при застосуванні комбінації ритуксимаб/ібрутиніб/леналідомід.

За даними L. Ceriani (Белінзона, Швейцарія) базовий метаболічний об'єм пухлини (MTV) є потужним прогностичним фактором у пацієнтів з ДВКЛ, що отримують терапію за схемою R-CHOP. Високий показник MTV прогнозує незадовільну відповідь на терапію, особливо у пацієнтів 3 nonGCB підтипом. Прогностична модель, що була побудована на комбінації MTV та метаболічної гетерогенності, може дозволити заздалегідь виявляти пацієнтів з високим ризиком прогресування захворювання.

P. Lugtenburg (Ротердам, Нідерланди) представив результати підтримувальної терапії ритуксимабом у пацієнтів 3 ДВКЛ у рамках дослідження III фази HOVON-NORDIC LYMPHOMA GROUP. Після спостереження впродовж 79,9 міс показник 5-річної БРВ становив 79\% для групи, що отримувала підтримувальну терапію ритуксимабом проти 74\% у групі спостереження. Різниця не була статистично значимою, отже, було зроблено висновок, що підтримувальна терапія із застосуванням ритуксимабу не покращує результати лікування хворих на ДВКЛ.

\section{ХРОНІЧнИЙ ЛІМФОЛЕЙКОЗ}

У рамках сесії, що була присвячена хронічному лімфолейкозу (ХЛЛ), А. Condoluci (Белінцона, Швейцарія) доповіла про новий прогностичний індекс при ранніх стадіях ХЛЛ. До цього індексу входять наступні змінні: лімфоцитоз $>15$ Г/л (відносний ризик $(\mathrm{BP})=2,6)$, лімфатичні вузли, що доступні для пальпації $(\mathrm{BP}=2,7)$, та немутований статус IGHV 
$(\mathrm{BP}=3,1)$. За цими змінними хворих розподілено на 3 групи ризику: низька - (0 балів), проміжна - (1 бал), високого ризику (2-3 бали) зі значимою різницею в показниках часу до призначення терапії. Згідно з цим індексом для пацієнтів низького ризику медіани часу до початку терапії не досягнуто, і через 10 років $77 \%$ пацієнтів не потребують специфічного лікування. У пацієнтів з проміжної групи ризику медіана часу до початку терапії становила 10,69 років (95\% довірчий інтервал (ДІ) 9,31-13,60). Серед хворих із групи високого ризику цей показник становив 3,89 року (95\% ДІ 3,56-4,30).

K. Fischer (Кельн, Німеччина) доповіла про результати терапії венетоклаксом та обінутузумабом протягом фіксованого періоду часу у пацієнтів з ХЛЛ, що не отримували іншої терапії раніше. Так, за даними дослідження у пацієнтів, що отримували 6 курсів терапії венетоклаксом 400 мг/добу в поєднанні з обінутузумабом (доза не вказана), вдалося досягти більш тривалих і глибоких відповідей з негативним статусом мінімальної резидуальної хвороби у порівнянні з пацієнтами, що отримували комбінацію обінутузумабу з хлорамбуцилом. За 24 міс спостереження показник БРВ становив $88 \%$ у групі венетоклакс + обінутузумаб та $64 \%$ - у групі хлорамбуцил + обінутузумаб $(\mathrm{p}<0,0001)$.

P. Ghia (Мілан, Італія) представив результати III фази клінічного дослідження «ASCEND». У рамках дослідження 310 пацієнтів були рандомізовані в 2 групи: пацієнти отримували акалабрутиніб (n=155) або іделалісиб/бендамустин ( $\mathrm{n}=155$ [іделалісиб, $\mathrm{n}=119$; бендамустин, $\mathrm{n}=36]$ ). БРВ на 12-му місяці спостереження становила $88 \%$ у групі хворих, яким було призначено акалабрутиніб, і $68 \%$ у групі пацієнтів, що отримували іделалісиб/бендамустин. Кращі показники БРВ були зареєстровані у хворих, які отримували акалабрутиніб, у тому числі серед пацієнтів $3 \operatorname{del}(17 \mathrm{p})$, мутацією ТР53. Таким чином, авторами було продемонстровано, що монотерапія акалобрутинібом значно покращує БРВ у пацієнтів з рецидивною/рефрактерною формоюХЛЛ і характеризується прийнятним профілем токсичності. За результатами рандомізованого міжнародного дослідження III фази RESONATE-2 (у дослідження були включені хворі на ХЛЛ, що раніше не отримували терапію та не мали делеції $17 \mathrm{p}$, віком $\geqslant 65$ років ( $\mathrm{n}=269))$ у групі пацієнтів, що отримували ібрутиніб (420 мг/добу), відмічалася краща ЗВ у порівнянні з хворими, що отримували хлорамбуцил $(0,5-0,8$ мг/кг до 12 циклів) (83 проти $68 \%$ через 5 років спостереження). За результатами дослідження CLL12 при застосуванні ібрутинібу у пацієнтів 3 ранніми стадіями ХЛЛ, що раніше не отримували терапії, суттєво покращується безподійна виживаність у порівнянні з пацієнтами, що отримували плацебо. У пацієнтів, що отримували ібрутиніб, також був суттєво довший час до початку нової лінії терапії. Однак результати дослідження не продемонстрували покращення ЗВ в групі хворих, які попередньо отримували лікування, i, можливо, щоб зробити остаточні висновки, необхідний більш тривалий період спостереження. Отже, на сьогодні тактика спостереження залишається золотим стандартом для таких хворих. Цікавим виявилося те, що частота небажаних явищ 3-4 ступеня токсичності та частота інфекцій не відрізнялася у цих двох групах.

\section{ТЕРАПЕВТИЧНІ ПІДХОДИ БЕЗ ЗАСТОСУВАННЯ XIMIOTEPAПIÏ}

Окрема секція була присвячена підходам у лікуванні без застосування хіміотерапії. А. Моссіа (Швейцарія) представив аналіз прогностичного значення показника прогресування захворювання до 24 міс при ФЛ за результатами 3 рандомізованих досліджень. Проаналізувавши результати терапії ритуксимабом або комбінації ритуксимабу і леналідоміду у 521 пацієнта, автори дійшли висновку, що цей показник зберігає своє прогностичне значення в незалежній когорті пацієнтів, що отримували лікування ФЛ без хіміотерапії. У дослідженні III фази «AUGMENT» були включені пацієнти з рецидивом/рефрактерною формою ФЛ 1-3а ступеня злоякісності, які раніше отримали більше ніж одну лінію системної терапії та були чутливі до ритуксимабу. Пацієнти отримували лікування за схемою R2 (леналідомід 20 мг/добу, Д1-21/28 Х12 циклів + ритуксимаб 375 мг/м², цикл 1, Д1, 8, 15, 22 і Д1 цикли 2-5) та ритуксимаб/плацебо (за тією ж схемою). Згідно з отриманими результатами, лікування в групі R2 (проти ритуксимаб/плацебо) знижує ризик рецидиву/прогресування на 59\% у пацієнтів з прогресуванням захворювання до 24 міс та підвишує частоту загальних відповідей та повних відповідей.

За даними проміжного аналізу мультицентрового дослідження IIIb фази «MAGNIFY», до якого були включені пацієнти з рецидивом або рефрактерною формою ФЛ 1-3а ступеня злоякісності та лімфомою маргінальної зони, загальна відповідь залежно від рефрактерності до ритуксимабу становила 63 та $78 \%$ у пацієнтів, що були рефрактерні до ритуксимабу, і у хворих без рефрактерності відповідно, частота повних відповідей становила 40 та 47\% відповідно. Таким чином, R2 терапія $\epsilon$ ефективним методом лікування у пацієнтів з рефрактерними формами та рецидивами індолентних лімфом, навіть за умови рефрактерності до ритуксимабу. У дослідженні I фази SAKK 35/15 вивчалася ефективність комбінації обінутузумабу та венетоклаксу у пацієнтів з ФЛ, що раніше не отримували лікування. Проведено аналіз результатів лікування з використанням цієї комбінації у 10 пацієнтів на 6-му місяці спостереження: у 5 зареєстровано повну відповідь (45\%; 95\% ДІ 17-77\%), часткову відповідь у 4 (36\%; 95\% ДІ 11-69\%), прогресування захворювання - у 2 пацієнтів, частота загальних відповідей становила $82 \%$ (95\% ДІ 48-98\%). Отже, згідно з проміжними результатами аналізу, досліджувана комбінація нових препаратів є досить ефективною у цій когорті пацієнтів.

Цікавими виявилися результати дослідження FOLL12, представлені М. Federico (Італія), згідно з якими у пацієнтів з проміжним та високим ризиком за FLIPI2, що потребують системної терапії, відсутність підтримувальної терапії ритуксимабом призводить до суттєвого зниження 3-річної БРВ, незалежно від статусу ПЕТ/КТ та мінімального залишкового захворювання (96 та 76\% відповідно).

\section{ВЕЛИКОКЛІТИННІ ЛІМФОМИ ВИСОКОГО РИЗИКУ}

У рамках клінічного дослідження II фази Північної Групи з вивчення лімфом (Nordic Lymphoma Group) (NLGLBC-05) проаналізовано вплив терапевтичного підходу «інтенсивність дози» та ранньої профілактики рецидиву з боку центральної нервової системи (ЦНС) на частоту рецидивів у ЦНС у хворих на ДВКЛ. Дослідження тривало з 2011 до 2014 р., групу спостереження становили пацієнти віком 18-64 років з первинною ДВКЛ, у тому числі пацієнти з BCL-2/MYC транслокаціями («double hit»), міжнародним прогностичним індексом (МПI) 2-3 або з наявністю ризик-факторів для розвитку рецидиву в ЦНС. Лікування складалося з проведення 2 курсів високодозового метотрексату в комбінації зі схемою $\mathrm{R}-\mathrm{CHOP}-14$ та подальшого проведення 4 додаткових курсів R-CHOP-14 з етопозидом та одним консолідуючим курсом високодозового цитарабіну. Хворим також призначали цитарабін інтратекально після 1-, 3- і 5-го курсів. При медіані спостереження 5 років БРВ, ЗВ та частота прогресування у ЦНС становили 74, 84 та 2,3\% відповідно. Отже, такий підхід знижує ризик прогресування з боку ЦНС у порівнянні з попереднім дослідженням NLG-LBC04, де системна профілактика ураження ЦНС проводилася після 6 курсів R-CHOEP-14 (BP=0,493; 95\% ДІ 0,312-0,780, $=0,003)$.

За попередніми результатами дослідження CRC-043 застосування венетоклаксу та DA-R-EPOCH добре переноситься та є ефективним режимом для терапії синдрому Ріхтера. Частота повних відповідей становила $67 \%$, БРВ/3В - 10/16,3 міс відповідно у порівнянні з історичним контролем. Набір пацієнтів у це дослідження ще триває, оновлені результати будуть представлені в майбутньому. 
У дослідженні $1 \mathrm{~b}$ фази «CAVALLI» оцінювали ефективність додавання венетоклаксу до стандартної схеми R-CHOP у пацієнтів з ДВКЛ з позитивною експресією BCL2. Група пацієнтів, що отримала стандартну терапію за схемою R-CHOP, була використана у якості історичного контролю на основі даних дослідження «GOYA». Частота повної відповіді не відрізнялася в двох групах (CAVALLI - 69\%; GOYA - 63\%), тоді як частота повних відповідей у пацієнтів з позитивною експресією BCL2 була нижчою у дослідженні GOYA. Таким чином, додавання венетоклаксу до стандартного курсу R-CHOP підвищує ефективність терапії для BCL2-позитивних пацієнтів з ДВКЛ.

\section{ЛІМФОМА ХОДЖКІНА}

За результатами мультицентрового аналізу 437 пацієнтів з I-II некласичним варіантом ЛХ нодулярного лімфоїдного переважання, представленого M.S. Binkley (США), медіана спостереження 5 років, виявилося, що показник 3В для пацієнтів з I-II стадіями досить високий і не залежить від виду терапії. Не зареєстровано різниці ЗВ у пацієнтів, що отримували хіміотерапію, та пацієнтів, що отримували тільки ПТ.

S. Ansell (США) представив результати 2-річного спостереження СНЕСКМАТЕ 205, у якому оцінюється ефективність ніволумабу в комбінації з AVD (доксорубіцин + вінбластин + дакарбазин) у пацієнтів 3 пізніми стадіями ЛХ. Такий підхід у терапії дозволяє досягти показника БРВ $83 \%$ на 21-му місяці спостереження, високі рівні метаболічних відповідей (75\% за критеріями IRC) із прийнятним профілем токсичності.

Результатами, що, можливо, змінять клінічну практику в найближчому майбутньому, стали дані, отримані у дослідженні HD0607 [3]. Досліджувану групу склали пацієнти з ЛХ, ст. IIB-IVB, що отримали 2 курси ABVD (доксорубіцин + блеоміцин + вінбластин + дакарбазин) 3 наступним ПЕТ/КТ-контролем. Хворі з негативними результатами ПЕT/KT отримували ще 4 курси ABVD і були рандомізовані у групи для проведення ПТ та без неї (за умови негативного ПЕТ/КТ-дослідження після завершення хіміотерапіі). Після медіани спостереження 5,9 років 6-річна БРВ для групи, що отримали ПТ, проти групи без ПТ становила 92\% (95\% ДІ 88-97\%) проти 90\% (95\% ДІ 85-95\%), p=0,48, а 6-річна 3В - 99\% (95\% ДІ 97-100\%) проти 98\% (95\% ДІ 96-100\%) відповідно. При проведенні додаткового аналізу для пацієнтів 3 наявністю великої пухлинної маси відмінності у групах також не були статистично значимими. Таким чином, авторами зроблено висновок, що пацієнтам з негативними проміжними і фінальними результатами ПЕТ/КТ можна не проводити ПТ, незалежно від розмірів уражених лімфатичних вузлів.

\section{НОВІ АНТИТІЛА}

У секції, присвяченій новим антитілам, доповідали про результати клінічних досліджень I фази із такими досліджуваними препаратами, як перше моноклональне антитіло анти-CD47 HU5F9-G4 (R.H. Advani, Стенфорд, США), REGN1979 - анти-CD20 Х анти-CD3 біспецифічне антитіло (M.S. Торр, Вьорцбург, Германія), CD20-TCB (RG6026) - новітне біспецифічне антитіло із залученням Т-клітин формату «2:1» (М.J. Dickinson, Мельбурн, Австралія) та ін.

\section{Т-КЛІТИНнІ ЛІМФОМИ}

У секції, присвяченій Т-клітинним лімфомам, P. Ghione (Нью-Йорк, США) розповів про Т-клітинні лімфоми, асоційовані з текстурованими імлантами грудних залоз. 31993 по 2017 p. 3546 пацієнток отримали 6023 хірургічних втручання з приводу реконструкції грудних залоз за допомогою грудних текстурованих імплантів. Медіана спостереження становила 7 років. У 8 жінок зареєстровано даний тип лімфоми у середньому через 11,2 року після його встановлення. Загальний ризик розвитку лімфоми, асоційованої з імплантатими грудних залоз у цій когорті, становив 0,294 випадку на 1000 осіб-років (1/443 жінки).
За даними M. Lopez-Parra (Саламанка, Іспанія) БРВ у пацієнтів з Т-клітинними лімфомами (за винятком ALK+ підтипу), що отримали АТСК у першій лінії терапії, БРВ становила 65\% у порівнянні з 44\% у пацієнтів без АТСК на 5-му році спостереження $(\mathrm{p}=0,012)$ та 3В -74 проти $65 \%(\mathrm{p}=0,046)$ відповідно. Переваги БРВ на користь групи хворих, що отримали АТСК, не залежали від МПІ чи типу першої лінії терапії при проведенні мультиваріантного Сох-аналізу (ВР 1,62, 95\% ДІ 1,03-2,54, $\mathrm{p}=0,35)$. Таким чином, було зроблено висновок, що АТСК в першій лінії терапії значно покращує виживаність пацієнтів з периферичними Т-клітинними лімфомами за винятком $\mathrm{ALK}+$ анапластичних великоклітинних лімфом.

За даними O. Tournilhac (Франція), 103 пацієнти з Т-клітинними лімфомами були рандомізовані у групи на проведення АТCK ( $\mathrm{n}=54)$ або алогенної трансплантації стовбурових клітин (ало-ТСК) (n=49). 36 пацієнтів (35\%) не отримали АТCK у зв'язку з прогресуванням захворювання. Медіана спостереження становила 42 міс. 3-річна БРВ та ЗВ не відрізнялися між групами пацієнтів, що отримали АТСК чи ало-ТСК (БРВ: 43\%; 95\% ДІ 29-57 проти 38\%; 95\% ДІ 25-52, $\mathrm{p}=0,58$, 3В: 57\%; 95\% ДІ 43-71\% проти 70\%; 95\% ДІ 57-82, p=0,41). У групі хворих, які отримали ало-ТСК, не було зареєстровано жодного рецидиву, однак 8 (31\%) пацієнтів померли від ускладнень у групі ало-ТСК, у той час як в групі хворих, які отримали АТСК, у 13 (36\%) осіб випадків рецидиву та смерті в результаті терапії зареєстровано не було.

\section{ВИСНОВКИ}

Згідно з рекомендаціями Міжнародної онкологічної групи з питань променевої терапії при лімфомах при плазмоцитомі доза 35-40 Гр є достатньою для опромінення невеликих пухлин, тоді як для пухлин $>5$ см слід застосовувати ПТ у дозі 40-50 Гр. А при застосуванні ПТ з паліативною метою оптимальною дозою є 10 Гр. При проведенні ПТ хворим на ДВКЛ слід враховувати, чи є пацієнт кандидатом на трансплантацію, і не забувати про можливе місце ПТ перед процедурою ВДХТ. При ДВКЛ, не дивлячись на суперечливі результати декількох останніх досліджень, стандартом терапії залишається режим R-CHOP. Численні дослідження направлені на пошук нових підходів до покращення режимів терапії хворих на ДВКЛ, зокрема «double/triple hit» - найбільш несприятливої групи пацієнтів. ВДХТ з АТСК у першій ремісії суттєво подовжує БРВ та ЗВ при МКЛ та периферичних Т-клітинних лімфомах (за винятком ALK + анапластичних великоклітинних лімфом). Допустимою опцією за наявності залишкової ПЕТпозитивної пухлини у середостінні після завершення лікування при ЛХ є тактика «очікуй і спостерігай» 3 повторним ПЕТ/КТдослідженням через 8-12 тиж та подальшою біопсією при сумнівних позитивних результатах ПЕТ/КТ за необхідності. Прогностичне значення при ДВКЛ має не тільки метаболічний об'єм пухлини до початку терапії, але і наявність метаболічної гетерогенності, що може стати новим важливим прогностичним фактором. У декількох дослідженнях продемонстровано ефективність підходів без хіміотерапії, однак частота побічних явищ свідчить, що лікування без хіміотерапії не завжди дорівнює лікуванню без токсичності. Результатами, шо, можливо, змінять клінічну практику в найближчому майбутньому, стали дані, отримані у дослідженні HD0607 A. Gallamini, які свідчать про відсутність переваг проведення ПТ пацієнтам з класичною ЛХ при IIB-IVB стадіях захворювання з негативними проміжними і фінальними результатами ПЕТ/КТ, незалежно від розмірів уражених лімфатичних вузлів. Усе більш актуальною стає проблема високої вартості та доступності високоефективних препаратів для лікування онкогематологічних хворих, що ставить питання про пошук шляхів вирішення цієї проблеми на різних рівнях (держави, фармацевтичних компаній, пацієнтів та професійних організацій). Тези презентацій наукової частини конгресу можна знайти на офіційному сайті www.lymphcon.ch/icml/website/index.php. 


\section{СПИСОК ВИКОРИСТАНОÏ ЛІТЕРАТУРИ}

1. Tsang, R., Campbell, B., Goda, J., Kelsey, C. R., Kirova, Y. M., Parikh, R. R. ... Yahalom, J. (2018). Radiation Therapy for Solitary Plasmacytoma and Multiple Myeloma: Guidelines From the International Lymphoma Radiation Oncology Group. Int $J$ Radiat Oncol Biol Phys, 101(4), 794-808. doi: 10.1016/j.jijrobp.2018.05.009.

2. Ng, A., Yahalom, J., Goda, J., Constine, L. S., Pinnix, C. C., Kelsey, C. R. .. Illidge, T. (2018). Role of Radiation Therapy in Patients With Relapsed/Refractory Diffuse Large B-Cell Lymphoma: Guidelines from the International Lymphoma Radiation Oncology Group. Int J Radiat Oncol Biol Phys, 100(3), 652-669, doi: Radiation Oncology Group.

3. Gallamini, A., Tarella, C., Viviani, S., Rossi, A., Patti, C., Mulé, A. Rambaldi, A. (2018). Early Chemotherapy Intensification With Escalated BEACOPP in Patients With Advanced-Stage Hodgkin Lymphoma With a Positive Interim Positron Emission Tomography/Computed Tomography Scan After Two ABVD Cycles: LongTerm Results of the GITIL/FIL HD 0607 Trial. J Clin Oncol, 36(5), 454-462. doi 10.1200/JCO.2017.75.2543.

\section{Обзор 15-го Международного конгресса, посвященного диагностике и лечению лимфом (ICML), Лугано, Швейцария, 18-22 июня 2019 г.}

А.В. Мартынчик, И.А. Крячок

Национальный институт рака, Киев

Резюме. В данной обзорной статье приведены важнейшие новые достижения, которые были представлены в г. Лугано, Швейцария, в рамках 15-го Международного Конгресса, посвященного диагностике и лечению лимфом (ICML). Освещены ключевые рекомендации Международной онкологической группы по вопросам лучевой терапии при лимфомах и приведены ссылки на рекомендации данной группы по лучевой терапии при диффузных В-крупноклеточных лимфомах и множественной миеломе/плазмоцитоме. Предоставлены окончательные и промежуточные результаты последних исследований при таких нозологиях, как хронический лимфолейкоз, индолентные лимфомы, крупноклеточные лимфомы высокого риска, лимфомы из клеток мантийной зоны, лимфома Ходжкина, приведена оценка эффективности новых моноклональных антител и других новейших исследуемых препаратов, а также возможности лечения лимфом без химиотерапии.
Ключевые слова: лимфома, лимфома Ходжкина, неходжкинская лимфома, множественная миелома, ICML, 15-й Международный конгресс, посвященный диагностике и лечению лимфом.

\section{Review of $15^{\text {th }}$ International Conference on Malignant Lymphoma (ICML), Lugano, Switzerland, 18-22 of June, 2019 \\ A.V. Martynchyk, I.A. Kriachok}

National Cancer Institute, Kyiv

Summary. This review article highlights the new data presented in Lugano, Switzerland within the 15th International Conference on Malignant Lymphoma (ICML). The key recommendations of the International Lymphoma Radiation Oncology Group are outlined, and references to this group's recommendations for radiation therapy for diffuse B-large lymphomas and multiple myeloma/plasmacytoma are provided. The final and interim results of recent studies in chronic lymphocytic leukemia, indolent lymphoma, high-risk large cell lymphoma, mantle cell lymphoma, Hodgkin lymphoma, assessment of the novel monoclonal antibodies and other novel agents, as well as chemotherapy-free options for lymphoma treatment.

Key words: Hodgkin lymphoma, non-Hodgkin lymphoma, multiple myeloma, ICML, $15^{\text {th }}$ International Conference on Malignant Lymphoma.

Адреса:
Мартинчик Арина Валерї̈вна
03022, Київ, вул. Ломоносова, 33/43
$\begin{aligned} & \text { Hаціональний інститут раку } \\ & \text { E-mail: aаrinka@gтаil.com }\end{aligned}$
$33 / 43$ Lomonosova Str., Kyiv 03022
National Cancer Institute
Correspondence:
E-mail: aarinka@gmail.com

